\title{
PELAKSANAAN TRADISI BASASULUH SUKU BANJAR PERSPEKTIF KONSEPSI KHITBAH SAYYID SABIQ (Studi di Desa Awang Bangkal Barat Kecamatan Karang Intan Kabupaten Banjar Kalimantan Selatan)
}

\author{
Logista Deny Saputra \\ Fakultas Syariah UIN Maulana Malik Ibrahim Malang \\ Email: putra_el_faruq@yahoo.com
}

\begin{abstract}
ABSTRAK
The discussion in this paper concentrates on Tradition Basasuluh contained in Banjar Tribe. In this tradition, there are some steps being taken by men that if the review of the concept of Sayyid Khitbah Sabiq have conformity and non-conformity, so need assessment and description of the implementation of Tradition Basasuluh Banjar tribe in terms of the concept of Sayyid Khitbah Sabiq. This research is an empirical study with a qualitative descriptive approach, and analyzed using the concept of Sayyid Khitbah Sabiq. The results of the analysis concluded that men should do Bacarian Tatuha Kampung, Bapara and Tuntung Pandang. Stages are not in accordance with the concept of Sayyid Khitbah Sabiq is Bacarian Tatuha Kampung and Tuntung Pandang, and appropriate is the stage Bapara. In accordance with the concept stage Bapara Khitbah Sayyid Sabiq because the essence of the thing is to know the condition and status of women desired men, well with intermediaries and direct others to ask themselves. Stages Bacarian Tatuha Kampung and Tuntung Pandang incompatible with the concept of Khitbah Sayyid Sabiq, because there is no essence of ease in these stages, while the concept of Khitbah Sayyid Sabiq facilitate ease in implementation Khitbah.

Pembahasan dalam tulisan ini berkonsentrasi pada Tradisi Basasuluh yang terdapat di Suku Banjar. Dalam tradisi tersebut terdapat beberapa tahapan yang dilakukan oleh laki-laki yang jika ditinjau dari konsep Khitbah Sayyid Sabiq memiliki kesesuaian dan ketidaksesuaian, sehingga perlu pengkajian dan pendeskripsian pelaksanaan Tradisi Basasuluh Suku Banjar ditinjau dari konsep Khitbah Sayyid Sabiq. Jenis penelitian ini adalah empiris dengan pendekatan deskriptif kualitatif, dan dianalisis menggunakan konsep Khitbah Sayyid Sabiq. Hasil analisis menyimpulkan bahwa pihak laki-laki harus melakukan Bacarian Tatuha Kampung, Bapara dan Tuntung Pandang. Tahapan yang tidak sesuai dengan konsep Khitbah Sayyid Sabiq adalah Bacarian Tatuha Kampung dan Tuntung Pandang, dan yang sesuai adalah tahapan Bapara. Pada tahapan Bapara sesuai dengan konsep Khitbah Sayyid Sabiq, sebab esensi hal tersebut adalah ingin mengetahui kondisi dan status dari perempuan yang diinginkan laki-laki, baik dengan perantara orang lain maupun langsung menanyakan sendiri. Tahapan Bacarian Tatuha Kampung dan Tuntung Pandang tidak sesuai dengan konsep Khitbah Sayyid Sabiq, sebab tidak ada esensi kemudahan dalam kedua tahapan tersebut, sedangkan konsep Khitbah Sayyid Sabiq mengutamakan kemudahan dalam pelaksanaan Khitbah.
\end{abstract}

Kata Kunci : Peminangan, Tradisi Basasuluh, Konsepsi Sayyid Sabiq 


\section{Latar Belakang Masalah}

Dari segi kehidupan masyarakat tradisional Suku Banjar selalu melakukan upacara-upacara yang bertujuan untuk menandai perubahan dari fase kehidupan ke fase lainnya yang terjadi dalam kehidupan masyarakat tersebut. Upacara-upacara tersebut terhimpun dalam suatu istilah yang dipergunakan oleh Suku Banjar, yaitu upacara Daur Hidup. Pada upacara Daur Hidup perubahan fase kehidupan ke fase yang selanjutnya sudah teradatkan dan sering dilakukan, sehingga apabia masyarakat Suku Banjar tidak melaksanakan salah satu dari upacara tersebut, masyarakat tersebut beranggapan bahwa akan mendapatkan kesialan atau bala, sehingga segala bentuk upacara tersebut harus dilaksanakan dalam satu kali kehidupan manusia yang bertujuan untuk menghindari atau menangkal segala kesialan atau bala.

Basasuluh merupakan salah satu rangkaian dari upacara-upacara adat dalam kategori upacara pernikahan yang dilaksanakan oleh masyarakat Suku Banjar. Istilah Basasuluh merupakan suatu kegiatan yang dilakukan oleh masyarakat Suku Banjar untuk memperoleh informasi yang pasti mengenai keadaan seorang gadis yang ingin dipinang oleh laki-laki. Selain itu Basasuluh juga berarti menyelidiki segala aspek kehidupan, baik kepada gadis yang dituju untuk dilamar maupun asal-usul keluarganya. ${ }^{1}$

Pada kenyataan yang terjadi dalam pelaksanaan prosesi Basasuluh yang dilakukan oleh masyarakat Suku Banjar, terdapat beberapa tahapan yang harus dilakukan oleh pihak keluarga laki-laki pada tahapan pertama pihak laki-laki harus meminta izin kepada perangkat desa untuk menikahi salah satu perempuan warga di desa setempat, kemudian mengunjungi Tatuha Kampung untuk mencarikan informasi mengenai kondisi dan status dari perempuan yang diinginkan dan selanjutnya menyimpulkan apakah laki-laki tersebut berjodoh dengan perempuan yang diinginkan

\footnotetext{
${ }^{1}$ Surinsyah Ideham dan Sjarifuddin (eds), Urang Banjar dan Kebudayaannya (Banjarmasin: Pemerintah Propinsi Kalimantan Selatan, 2007), h. 50.
}

berdasarkan perhitungan nama kedua belah pihak yang berbentuk Huruf Arab.

Dalam melaksanakan prosesi ini, Tatuha Kampung yang diutus melakukan penyelidikan terhadap gadis tersebut menyangkut hal-hal tentang agamanya, keturunannya, kemampuan keluarganya dan kecantikan wajahnya. ${ }^{2}$ Dari aspek-aspek yang diselidiki oleh utusan keluarga laki-laki yang menjadi titik tumpu perhatian adalah aspek keagamaan dan keturunan. ${ }^{3}$ Hal ini menggambarkan bahwa masyarakat Suku Banjar sangat memegang teguh tentang tingkat religiusitas seseorang yang akan menjalani biduk rumah tangga. Selain itu, aspek keturunan pun menjadi pertimbangan dalam menentukan langkah selanjutnya dalam prosesi pra nikah. Sebab hal ini menjadi tolok ukur bagi kepribadian seorang gadis yang akan dilamar. Setelah melakukan hal tersebut Tatuha Kampung juga melakukan perhitungan nama kedua belah pihak yang berbentuk Huruf Arab yang hasil dari perhitungan tersebut menjadi patokan dan kesimpulan bagi Tatuha Kampung dalam menentukan apakah keduabelah pihak tersebut berjodoh dan memiliki kecocokan atau tidak. Apabila keduabelah pihak tidak berjodoh atau tidak memiliki kecocokan berdasarkan perhitungan tersebut, maka pihak laki-laki harus membatalkan niatnya untuk melamar dan menikahi perempuan tersebut dan mencari perempuan lain yang memiliki kecocokan dengannya, meskipun perempuan tersebut memiliki kriteria yang sesuai dengan keinginan pihak laki-laki. Namun, apabila dari hasil perhitungan tersebut menyatakan dan menyimpulkan bahwa keduabelah pihak memimliki kecocokan dan berjodoh, maka pihak laki-laki dapat melanjutkan pada jenjang tradisi selanjutnya yang ada pada tradisi masyarakat Suku Banjar.

Pihak laki-laki yang ingin melamar perempuan tersebut harus mengikuti dan melaksanakan rentetan tahapan yang ada dalam

\footnotetext{
${ }^{2}$ anastasyaitsreal.blogspot.com/2012/11/perkawinanadat-banjar-kecamatan-nagara/, diakses pada tanggal 9 Mei 2013.

${ }^{3}$ Syamsiar seman, Perkaawinan Adat Banjar Kalimantan Selatan, (Cet. 6; Banjarmasin: Lembaga Pengkajian \& Pelestarian Budaya Banjar, 2011), h. 2.
} 
tradisi Basasuluh serta mengikuti petuah dari Tatuha Kampung, sehingga menjadi anggapan masyarakat bahwa apabila tidak melaksanakan salahsatu tahapan dari tradisi tersebut, kedua belah pihak akan dikucilkan oleh masyarakat sekitar dan ketika menjalani biduk rumah tangga dianggap keluarganya kelak akan mendapat bala bencana.

Tradisi Basasuluh ini adalah upaya awal bagi pihak laki-laki dalam mengetahui segala macam informasi yang berkaitan dengan calon istrinya kelak, sehingga menjadi sebuah kewajiban untuk dilaksanakan dalam fase pra nikah, yang kemudian terkonversi menjadi adat Suku Banjar secara turun-temurun.

Allah S.W.T telah menyinggung tentang Khitbah atau peminangan dalam alQuran yang berbunyi:

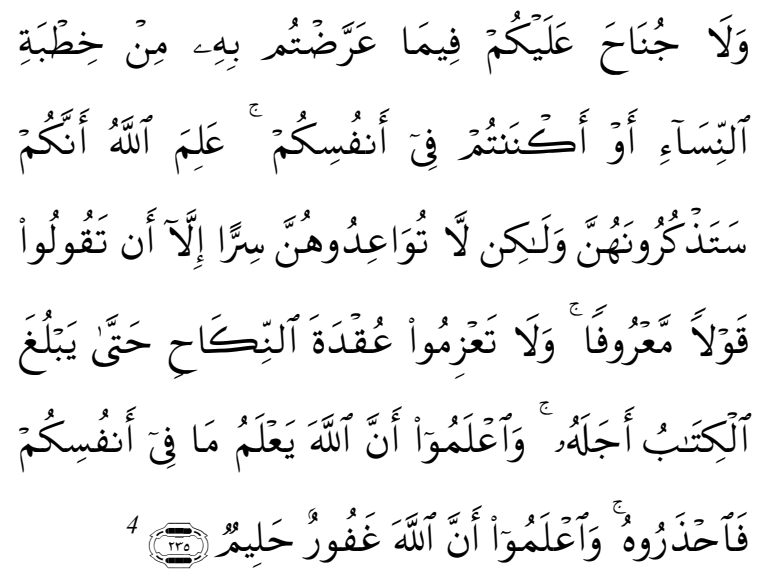

"Dan tidak ada dosa bagi kamu meminang wanita-wanita itu dengan sindiran atau kamu Menyembunyikan (keinginan mengawini mereka) dalam hatimu. Allah mengetahui bahwa kamu akan menyebut-nyebut mereka, dalam pada itu janganlah kamu Mengadakan janji kawin dengan mereka secara rahasia, kecuali sekedar mengucapkan (kepada mereka) Perkataan yang ma'ruf. Dan janganlah kamu ber'azam (bertetap hati) untuk beraqad nikah, sebelum habis 'iddahnya. Dan ketahuilah bahwasanya Allah mengetahui apa yang ada dalam hatimu; Maka takutlah kepada-Nya, dan ketahuilah bahwa Allah Maha Pengampun lagi Maha Penyantun".

Adapun dalam prosesi pra nikah yang dianjurkan dengan konsep Khitbah menurut

${ }^{4}$ QS. al-Baqarah (2): 235
Sayyid Sabiq dalam kitab Fiqih Sunnah adalah

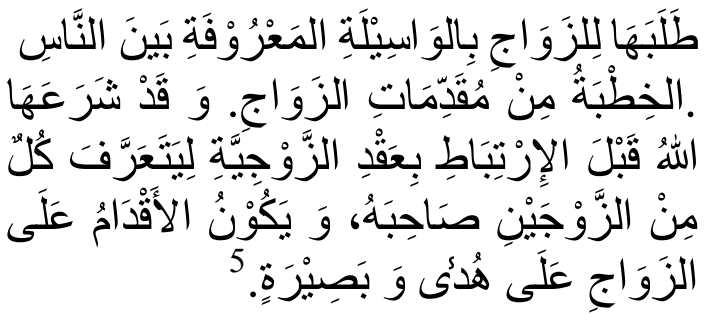

"Meminang maksudnya seorang laki-laki meminta kepada seorang perempuan untuk menjadi isterinya, dengan cara-cara yang sudah umum berlaku di tengah-tengah masyarakat. Meminang termasuk usaha pendahuluan dalam rangka perkawinan. Allah menggariskan agar masing-masing pasangan yang mau kawin, lebih dahulu saling mengenal sebelum aqad nikahnya, sehingga pelaksanaan perkawinan benarbenar berdasarkan pandangan dan penilaian yang jelas". 6

Berdasarkan penjelasan yang penulis sebut diatas, maka Sayyid Sabiq mengisyaratkan bahwa peminangan dilakukan antara laki-laki dengan perempuan yang disaksikan langsung oleh masing-masing keluarga besar dan menggunakan aturan dalam hukum Islam. Hal tersebut menimbulkan perbedaan secara konsep antara fenomena Basasuluh yang menjadi Tradisi dalam Suku Banjar dengan konsep Khitbah yang dijelaskan dan dianjurkan oleh Sayyid Sabiq dalam Fiqih Sunnahnya. Selain itu, aspek kemudahan dalam melakukan kebaikan sebagaimana yang menjadi esensi dalam konsep Khitbah yang disebutkan oleh Sayyid Sabiq dalam kitab beliau ataupun dalam mazhab yang mayoritas dianut oleh rakyat Indonesia yaitu Mazhab Syafi'i mengenai prosesi sebelum pelaksanaan peminangan terhadap perempuan, tidak terakomodir dalam pelaksanaan tradisi ini.

Maka dari itu, penulis perlu kiranya untuk membahas antara Hukum Islam yang menyinggung tentang konsep Khitbah menurut Sayyid Sabiq dalam kitabnya Fiqih Sunnah dengan Tradisi pra nikah Suku Banjar, yaitu Tradisi Basasuluh dalam merealisasikan tujuan dari pernikahan, yaitu mewujudkan kehidupan

\footnotetext{
${ }^{5}$ Sayyid Sabiq, Fikih Sunnah, Juz II (Cet. XXI; Dâr alHadîts al-Qâhirah, 2009), h. 16.

${ }^{6}$ Sayyid Sabiq, Fikih Sunnah 6, terj. Drs. Moh Thalib, (Cet. I; Bandung: PT. Alma'arif, 1980), h. 30-31
} 
rumah tangga yang sakinah, mawaddah, dan rahmah. $^{7}$ Selain itu pula, penulis berupaya memperkenalkan dan mengangkat kembali Tradisi Basasuluh kepada pembaca ataupun peneliti selanjutnya, agar senantiasa mampu bertahan dalam derasnya arus perkembangan zaman dan mampu menjadikan Basasuluh sebagai ciri khas dari sistem perkawinan adat Suku Banjar.

\section{Metode Penelitian}

Pada penelitian kali ini, penulis menggunakan jenis penelitian empiris. Yaitu penelitian yang berkaitan dengan pendapat dan perilaku anggota masyarakat dalam hubungan hidup bermasyarakat. ${ }^{8}$ Dengan kata lain, penelitian empiris mencoba untuk mengungkapkan implementasi hukum yang hidup atau hukum yang berlaku ditengah masyarakat melalui perbuatan atau perilaku merekadalam hubungan hidup bermasyarakat. Dalam hal ini penulis mencoba untuk mengungkapkan realita pengimplementasian hukum dalam kehidupan masyarakat Suku Banjar yang bersinergi dengan salah satu prosesi pra nikah yang disebut dengan Basasuluh atau prosesi Khitbah dalam istilah ilmu fiqih.

Pada penelitian kali ini penulis menggunakan pendekatan penelitian kualitatif. Yaitu penelitian yang berlandaskan pada filsafat postpositivisme, digunakan untuk meneliti pada kondisi obyek yang alamiah, (sebagai lawannya adalah eksperimen) dimana peneliti adalah sebagai instrument kunci, teknik pengumpulan data dilakukan dengan cara triangulasi atau gabungan, analisis data bersifat induktif atau kualitatif, dan hasil penelitian lebih menekankan pada makna daripada penekanan terhadap generalisasi obyek yang diteliti. $^{9}$

Dalam pengolahan data, tergantung pada sifat yang dikumpulkan oleh penulis (terhadap pengumpulan data) yang bertujuan untuk kevalidan data yang diperoleh melalui

\footnotetext{
${ }^{7}$ KHI, Bab II Dasar-dasar Perkawinan, Pasal 3. ${ }^{8}$ Fakultas Syari'ah. Pedoman Penelitian Karya Ilmiah, (Malang: Fakultas Syariah, 2012), h. 25.

${ }^{9}$ Sugiyono. Metode Penelitian Kuantitatif, Kualitatif dan $R \& D$, (Bandung: Alfabeta, 2008), h. 9.
}

informasi yakni masyarakat. ${ }^{10}$ Dalam penelitian ini sesuai dengan uraian diatas, maka penulis akan mendeskripsikan tentang data dan informasi dari masyarakat Suku Banjar di Desa Awang Bangkal Kecamatan Karang Intan Kabupaten Banjar Kalimantan Selatan yang telah penulis kumpulkan. Kemudian dari data dan informasi tersebut penulis akan menceritakan tentang data Suku Banjar yang berdomisili di Desa Awang Bangkal Kecamatan Karang Intan Kabupaten Banjar Kalimantan Selatan, informasi tentang tradisi basasuluh dalam prosesi pra nikah yang dilakukan oleh Suku Banjar serta tinjauan tradisi tersebut dengan konsepsi khitbah yang dirumuskan oleh Sayyid Sabiq dalam kitab Fiqih Sunnah. Namun, sebelum penulis merekapitulasi data yang telah penulis peroleh, penulis terlebih dahulu melakukan pengelolaan data dan informasi yaitu : yang pertama edit atau Editing merupakan proses penelitian kembali terhadap catatan, berkas-berkas, informasi dikumpulkan oleh para pencari data. ${ }^{11}$ Pada pengelolaan data dengan cara editing atau pengeditan, penulis akan memeriksa kembali atas data-data yang diperoleh dari lapangan, baik data primer maupun sekunder yang berkaitan dengan tradisi basasuluh yang dilakukan oleh Suku Banjar di Desa Awang Bangkal Kecamatan Karang Intan Kabupaten Banjar Kalimantan Selatan dengan tujuan untuk mengetahui kelengkapan data dan kesesuaiannya dengan tema penelitian yang penulis lakukan, sehingga penulis dapat mengetahui kekurangan dan kesalahan data untuk menghindari ketidaksesuaian data dengan tema yang penulis teliti. Yang kedua Klasifikasi merupakan proses pengelompokan data yang penulis baca kembali dengan seksama dan teliti, sehingga penulis dapat membedakan data yang penuis peroleh dari lapangan mengenai kesesuaiannya dengan metode pengumpuan data yang penulis gunakan pada penelitian kali ini, yaitu wawancara dan dokumentasi. Kemudian, setelah penulis membedakan data sesuai dengan metode pengumpulan data yang penulis

\footnotetext{
${ }^{10}$ Amiruddin dan Zaenal Asikin, "Pengantar Metode Penelitian Hukum" (Jakarta: PT.Raja Grafindo Persada, 2003), 168.

${ }^{11}$ Ibid.
} 
gunakan pada penelitian kali ini, penulis menggolongkan data tersebut sesuai dengan rumusan masalah yang penulis cantumkan pada latar belakang penelitian ini, sehingga dari pengklasifikasian data-data yang penulis dapatkan tersebut, nantinya akan penulis bandingkan dengan teori yang telah penulis dapatkan dari literatur-literatur mengenai Tradisi Basasuluh, sehingga dapat menjawab dari rumusan masalah pada penelitian ini. Klasifikasi bertujuan untuk memudahkan pembaca dalam memaknai isi penelitian ini. Yang ketiga Verifikasi merupakan suatu tindakan untuk mencari kebenaran tentang data dan informasi yang telah diperoleh, sehingga hasil penelitian ini dapat diyakini kebenarannya secara akurat. Dalam hal ini penulis menemui kembali responden yang telah diwawancarai atau dimintai informasi tentang Tradisi Basasuluh di Desa Awang Bangkal Kecamatan Karang Intan Kabupaten Banjar Kalimantan Selatan untuk membaca ulang hasil wawancara setalah diberi tanggapan sehingga reponden dapat mengetahui kebenaran maupun kesalahan ungkapannya terhadap pertanyaan yang disajikan oleh penulis. Selain itu pada tahap verifikasi ini, penulis memeriksa keabsahan data yang penulis peroleh dari lapangan dengan tema yang penulis angkat pada penellitian kali ini, sehingga data yang penulis dapatkan dari lapangan melaui metode pengumpulan data, dapat dipertanggungjawabkan dan kuat. Yang keempat adalaha analisis. Dalam analisis ini, pada awalnya penulis menyebutkan paparan data dari hasil wawancara yang penulis lakukan kepada masyarakat Suku Banjar di Desa Awang Bangkal Kecamatan Karang Intan Kabupaten Banjar Kalimantan Selatan. Kemudian setelah itu penulis menganalisis hasil dari wawancara penulis terhadap responden sesuai dengan pengklasifikasiannya masing-masing yang kemudian dianalisis sesuai dengan buku-buku yang berkaitan dengan peminangan atau khitbah. Dalam hal ini hasil pemikiran Sayyid Sabiq yang tertuang dalam kitab Fiqih Sunnah, yang menyinggung tentang khitbah. Kemudian setelah data-data tersebut penulis analisis menggunakan Kitab Fiqih Sunnah karangan Sayyid Sabiq, penulis sudah memiliki gambaran mengenai jawaban dari rumusan masalah yang penulis cantumkan dalam penelitian ini. Yang kelima adalah
Kesimpulan. Tahapan ini penulis melakukan langkah terakhir dari pengolahan data yang telah penulis peroleh berbagai pihak dan literatur yaitu pengambilan kesimpulan dari data-data yang telah penulis olah untuk mendapatkan suatu jawaban dari rumusan masalah yang penulis cantumkan pada penlitian ini. Pada tahap ini penulis sudah menemukan jawaban-jawaban dari hasil penelitian yang telah dilakukan yang akan digunakan untuk membuat kesimpulan. Kemudian penulis dapat menghasilkan gambaran secara ringkas, jelas dan mudah dipahami.

\section{Tinjauan Tradisi Basasuluh Suku Banjar dari konsep Khitbah Sayyid Sabiq.}

Meminang termasuk salah satu hal yang diharuskan kepada seseorang yang ingin menikah. Hal tersebut dilakukan terlebih dahulu untuk mengetahui segala bentuk informasi dan kondisi dari kedua belah pihak yang ingin melangsungkan pernikahan, agar setelah mengetahui informasi dan kondisi dari masing-masing pihak tidak ada lagi penyesalan dikemudian hari atau bahkan dapat menjadi sebab keretakan rumah tangga yang telah dibangun.

Sayyid Sabiq secara jelas menyebutkan dalam kitab Fiqih Sunnah bahwa peminangan adalah :

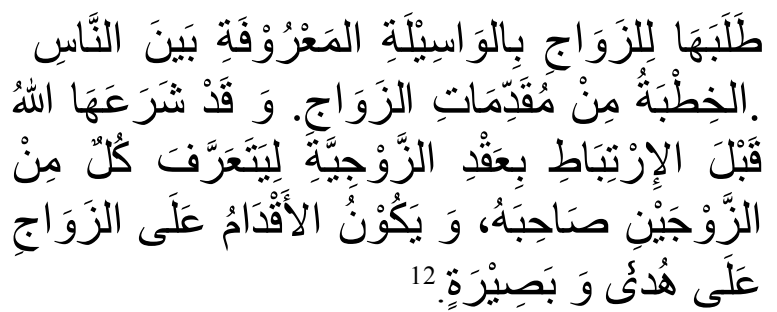

"Meminang maksudnya seorang laki-laki meminta kepada seorang perempuan untuk menjadi isterinya, dengan cara-cara yang sudah umum berlaku di tengah-tengah masyarakat. Meminang termasuk usaha pendahuluan dalam rangka perkawinan. Allah menggariskan agar masing-masing pasangan yang mau kawin, lebih dahulu saling mengenal sebelum aqad nikahnya, sehingga pelaksanaan perkawinan benar-benar berdasarkan pandangan dan penilaian yang jelas". ${ }^{13}$

\footnotetext{
${ }^{12}$ Sabiq, Fikih Sunnah, Juz II, h. 16.

${ }^{13}$ Sabiq, Fikih Sunnah 6, terj. Drs. Moh Thalib, h. 30-31
} 
Sebagai suatu hal yang terlebih dahulu dilaksanakan sebelum adanya pernikahan, peminangan merupakan hal yang sangat penting bagi pihak laki-laki ataupun pihak perempuan. Karena dengan melaksanakan peminangan masing-masing pihak dapat saling mengetahui kekurangan dan kelebihan dari kedua belah pihak, mulai dari bagaimana perilakunya, keturunannya, agamanya, paras wajahnya, perekonomiannya dan yang paling penting adalah bagaimana kondisi dari pihak perempuan yang ingin dinikahi. Sebab apabila perempuan tersebut masih dalam kondisi ada halangan secara hukum untuk dipinang, maka pihak laki-laki dapat memahami dan memaklumi, sehingga menggunakan cara lain kalau memang hanya ingin menikahi perempuan tersebut.

Pada penelitian kali ini, penulis mencoba untuk meninjau sebuah tradisi pernikahan masyarakat Suku Banjar yang berdomisili di Desa Awang Bangkal Barat, yaitu Tradisi Basasuluh dengan konsep Khitbah yang digunakan oleh Sayyid Sabiq dalam meminang.

Sebagaimana yang telah penulis paparkan pada pembahasan sebelumnya bahwa Tradisi Basasuluh adalah salah satu tradisi yang ada pada masyarakat Suku Banjar yang berdomisili di Desa Awang Bangkal Barat, dan termasuk dalam upacara pra nikah masyarakat Suku Banjar, yang bertujuan untuk mencari informasi mengenai perempuan yang akan dinikahi.

Dalam tradisi tersebut terdapat beberapa tahapan yang harus dilakukan oleh pihak laki-laki sebelum resmi melamar perempuan yang diinginkan, yaitu:

\section{Bacarian Tatuha Kampung.}

Pada tahap awal dalam Tradisi Basasuluh adalah tahap Bacarian Tatuha Kampung. Pada tahap ini pihak laki-laki berusaha mencari orang yang dianggap berpengaruh dan sangat mengetahui seluk beluk desa tersebut dan kondisi masyarakatnya melalui perangkat desa setempat. Hal tersebut dilakukan untuk menghormati perangkat desa setempat sebagai reprsenatsi masyarakat desa tersebut. Sebab perangkat desa merupakan salah satu orang yang dianggap masyarakat Suku Banjar yang berdomisili di Desa Awang
Bangkal Barat sebagai Tatuha Kampung. Namun, strata beliau masih dibawah strata Tatuha Kampung yang dimintai pendapat dan arahan dalam pernikahah. Sebab menurut kepercayaan Suku Banjar Tatuha Kampung tersebut memiliki ilmu kebatinan yang mampu melihat masa depan dari hal yang direncanakan. Jadi, sebelum menemui Tatuha Kampung, pihak laki-laki harus menemui perangkat desa terlebih dahulu untuk meminta informasi mengenai tempat tinggal Tatuha Kampung. Apabila hal tesebut tidak dilakukan oleh pihak laki-laki, maka akan dikucilkan atau dicibir oleh masyarakat sekitar dan tidak dapat melanjutkan ke tahap berikutnya, yaitu Bapara. Sebab Tatuha Kampung tidak akan menerima keluarga laki-laki di tempat tinggal beliau apabila masih belum mendapatkan izin dari perangkat desa setempat.

Jika ditinjau dari ketentuan meminang atau mengkhitbah dalam kitab Fiqih Sunnah karangan Sayyid Sabiq yang menyebutkan bahwa :

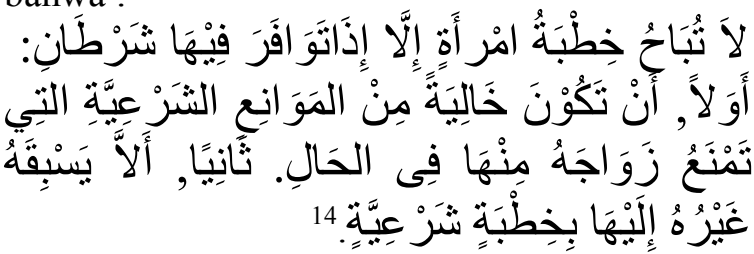

"perempuan yang boleh dipinang bilamana memenuhi dua syarat yaitu : pertama, pada waktu dipinang tidak ada halangan-halangan hukum yang melarang dilangsungkannya perkawinan. Kedua, belum dipinang orang lain secara sah. ${ }^{15}$

Dari persyaratan untuk meminang perempuan yang disebutkan dalam kitab Fiqih Sunnah Sayyid Sabiq, mengandung indikasi bahwa apabila seorang laki-laki ingin meminang seorang perempuan harus menge-tahui kondisi dan status dari perempuan yang ingin dipinang. Sebab jika perempuan tersebut tidak memenuhi persyaratan tersebut, maka tidak dapat dipinang oleh laki-laki tersebut. Selain itu, dalam persyaratan tersebut terdapat indikasi pula bahwa pihak laki-laki tersebut juga harus mendapatkan izin dari wali atau orang tua perempuan yang diinginkannya.

\footnotetext{
${ }^{14}$ Sabiq, Fikih Sunnah, Juz II, h. 16.

${ }^{15}$ Sabiq, Fikih Sunnah 6, terj. Drs. Moh Thalib, h. 31.
} 
Sedangkan apabila dicermati secara mendalam, tahapan Bacarian Tatuha Kampung pada intinya seorang yang ingin menikah dengan salah satu warga desa, haruslah menghormati masyarakat di desa tersebut. Sebab laki-laki tersebut sama saja akan mengambil aset atau sesuatu yang berharga bagi masyarakat di desa tersebut, dalam hal ini perempuan yang ingin dinikahi oleh laki-laki tersebut. Maka dari itu laki-laki tersebut diharuskan untuk meminta izin kepada representasi masyarakat Desa Awang Bangkal Barat, yaitu perangkat desa.

Dari analisis penulis mengenai maksud dari tahapan Bacarian Tatuha Kampung dengan indikasi dari persyaratan yang harus dipenuhi oleh perempuan yang akan dipinang sebagaimana tercantum dalam kitab Fiqih Sunnah karangan Sayyid Sabiq, maka tidak ada kesesuaian antara kedua hal tersebut. Sebab maksud dan tujuan dari prosesi Bacarian Tatuha Kampung adalah untuk menghormati dan memohon izin kepada rmasyarakat Desa Awang Bangkal Barat karena akan menikahi salah satu perempuan warga desa tersebut. Sedangkan maksud dan tujuan dari persyaratan yang harus dipenuhi oleh perempuan yang akan dipinang sebagaimana tercantum dalam kitab Fiqih Sunnah karangan Sayyid Sabiq adalah pihak laki-laki harus terlebih dahulu harus mengatahui kondisi dan status dari perempuan yang akan dipinang dan memohon izin kepada wali atau orang tuanya saja bukan pada representasi masyarakat sekitar, yaitu perangkat desa. Maka dari pada itu antara kedua hal tersebut berbeda dari segi maksud dan tujuannya, sehingga tidak ada kesesuaian yang terkandung dari kedua hal tersebut.

\section{Bapara.}

Pada tahapan yang kedua dalam Tradisi Basasuluh yang dilakukan oleh masyarakat Suku Banjar yang berdomisili di Desa Awang Bangkal Barat adalah prosesi Bapara. Pada prosesi Bapara ini laki-laki yang telah mendapatkan izin dari perangkat desa dan menerima informasi mengenai nama dan tempat tinggal Tatuha Kampung di Desa Awang Bangkal Barat, mengunjungi tempat tinggal Tatuha Kampung bersama seluruh keluarga dari pihak laki-laki dan ditemani oleh perangkat desa sebagai simbol pemeberian izin kepada laki-laki dan keluarganya untuk menikahi salah satu perempuan warga Desa Awang Bangkal Barat.

Maksud dan tujuan dari prosesi ini adalah untuk menyampaikan kepada Tatuha Kampung mengenai keinginan pihak keluarga laki-laki untuk menikahi salah satu perempuan warga Desa Awang Bangkal Barat, yang kemudian Tatuha Kampung dapat mencarikan perempuan yang sesuai dengan keinginan dari pihak keluarga laki-laki. Selain itu, pihak lakilaki juga mengharapkan pendapat dan arahan dari Tatuha Kampung mengenai kecocokan dan tingkat perjodohan antara kedua belah pihak, agar hubungan keluarga diantara keduanya dapat langgeng sampai akhir umur mereka. Artinya pihak keluarga laki-laki melimpahkan kuasa terhadap Tatuha Kampung untuk mencarikan perempuan sesuai dengan kriteria atau ciri-ciri yang diinginkan oleh pihak keluarga laki-laki, yang kemudian perempuan tersebut akan dinikahi oleh laki-laki tersebut.

Kemudian penulis akan menggunakan konsep Khitbah dari Sayyid Sabiq mengenai ketentuan meminang perempuan. Menurut beliau :

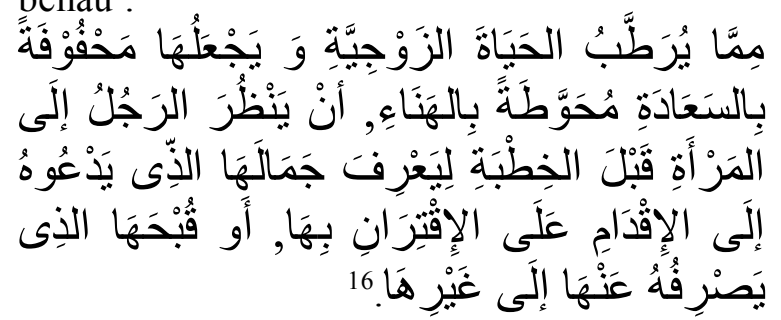

"Guna baiknya kehidupan bersuami istri, kesejahteraan dan ketenteramannya, seyogyanyalah laki-laki lebih dahulu melihat perempuan yang akan dipinangnya, sehingga dapat diketahui kecantikannya yang bisa menjadi salah satu faktor menggalakkan dia untuk mempersuntingnya, atau untuk mengetahui cacat-celanya yang bisa menjadi penyebab kegagalannya sehingga berganti mengambil orang lain ",17

Dari pernyataan beliau mengenai tindakan pihak laki-laki yang ingin meminang seorang perempuan, dapat dipahami bahwa laki-laki tersebut diharuskan untuk lebih mengetahui tentang kondisi dan status dari perempuan tersebut dengan cara langsung

\footnotetext{
${ }^{16}$ Sabiq, Fikih Sunnah, Juz II, h. 18.

${ }^{17}$ Sabiq, Fikih Sunnah 6, terj. Drs. Moh Thalib, h. 35.
} 
melihat perempuan tersebut, sehingga dapat diketahui paras wajahnya yang akan menjadi faktor untuk lebih membulatkan tekad pihak laki-laki yang akan meminang perempuan tersebut.

Setelah mengetahui dari segi paras wajah dari perempuan yang akan dipinang, selanjutnya pihak laki-laki juga perlu untuk mengetahui sifat, prilaku dan kepribadian dari perempuan tersebut, dan kembali Sayyid Sabiq menjelaskan mengenai hal tersebut dalam Fiqih Sunnahnya, yaitu :

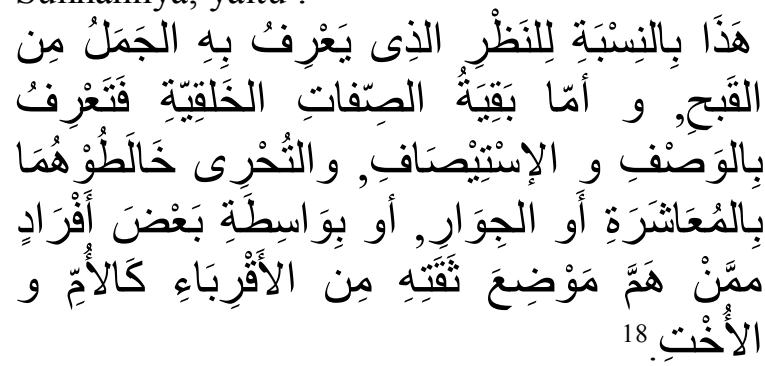

"dengan melihat, dapat diketahui cantik atau jeleknya seseorang perempuan. Adapun sifatsifat yang bertalian dengan akhlak, dapatlah diketahui dari sifat lahirnya atau ditanyai atau bertanya kepada mereka-mereka yang dekat dengannya, atau mellalui tetangganya, atau dengan perantara menanyai kalangan keluarganya yang sangat dipercayainya seperti ibu dan saudara-saudara perempuannya",19

Dari penjelasan beliau, dapat penulis ambil pemahaman bahwa setelah pihak lakilaki mengetahui tentang perempuan yang ingin dipinang dari segi paras wajahnya yang berguna untuk membulatkan tekad pihak lakilaki apabila ingin menikahinya, setelah itu barulah perlu mengetahui mengenai perempuan tersebut dari segi sifat, prilaku dan akhlaknya. Hal tersebut dapat diketahui melalui bertanya langsung kepada keluarga yang bersangkutan dan dapat dipercayai informasinya, atau dengan cara mengutus seseorang untuk menanyakan mengenai hal tersebut kepada keluarga dekatnya seperti ibu dan saudara perempuannya atau juga dapat ditanyakan kepada tetangganya.

Dalam kitab Fiqih Sunnah, Sayyid Sabiq menyebutkan sebuah Hadits yang menerangkan bahwa Nabi pernah mengutus

\footnotetext{
${ }^{18}$ Sabiq, Fikih Sunnah, Juz II, h. 19.

${ }^{19}$ Sabiq, Fikih Sunnah 6, terj. Drs. Moh Thalib, h. 37.
}

Ummu Sulaim untuk mendatangi seorang perempuan, lalu sabda beliau:

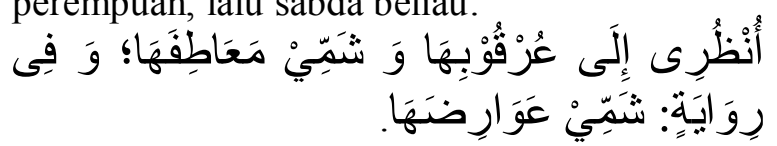

Artinya : "Lihatlah urat kentirnya dan ciumlah kuduknya. Dalam riwayat lain dikatakan: dan ciumlah gigi depannya" (HR. Ahmad, Hakim, Tabrani dan Baihaqiy) ${ }^{20}$

Dari ketentuan yang Sayyid Sabiq sebutkan dalam Kitab Fiqih Sunnah dan tercantum dalam kitab beliau yang menerangkan bahwa Nabi pernah mengutus orang untuk mengetahui perihal seorang perempuan, dapat penulis ambil pemahaman, yaitu apabila laki-laki yang ingin meminang perempuan hendaknya mengetahui terlebih dahulu tentang kondisi, paras wajah, sifat dan prilaku perempuan yang akan dipinang, baik dengan cara langsung bertanya kepada pihak keluarga perempuan yang dianggap mengetahui dan memahami perempuan ter-sebut atau mengutus seseorang yang dipercaya untuk menanyakan mengenai hal tersebut kepada keluarga perempuan.

Dari pejelasan antara prosesi Bapara yang termasuk salah satu tahapan dalam Tradisi Basasuluh masyarakat Suku Banjar yang berdomisili di Desa Awang Bangkal Barat dengan konsep Khitbah Sayyid Sabiq dapat diambil pemahaman bahwa kedua hal tersebut memiliki keterkaitan dan sesuai, baik dari segi maksud ataupun dari segi tujuannya, sehingga sangat baik untuk dilaksanakan bagi seseorang yang ingin meminang perempuan. Hal tersebut ditunjukkan dengan pelimpahan kuasa oleh pihak keluarga laki-laki kepada Tatuha Kampung untuk menanyakan kondisi, paras wajah, sifat dan prilaku dari perempuan yang ingin dipinang oleh laki-laki tersebut, dan hal tersebut dilakukan pula oleh Nabi ketika beliau ingin mengetahui kondisi dari perempuan yang ingin beliau selidiki.

3. Tuntung Pandang.

Tahapan yang terakhir dari Tradisi Basasuluh masyarakat Suku Banjar yang berdomisili di Desa Awang Bangkal Barat adalah prosesi Tuntung Pandang. Pada prosesi ini, Tatuha Kampung sudah mulai menanyakan perihal perempuan yang diinginkan oleh pihak

\footnotetext{
${ }^{20}$ Sabiq, Fikih Sunnah 6, terj. Drs. Moh Thalib, h. 37.
} 
laki-laki kepada keluarganya dan tetanganya. Hal-hal yang ditanyakan Tatuha Kampung kepada keluarga perempuan tersebut merupakan kriteria yang diinginkan oleh pihak laki-laki dan telah diungkapkan ketika berkunjung ke tempat tinggal Tatuha Kampung pada prosesi sebelumnya, yaitu prosesi Bapara.

Hal-hal yang ditanyakan oleh Tatuha Kampung kepada keluarga perempuan dan tetangga sekitar rumahnya adalah mengenai perekonomian keluarga tersebut, tingkat religiusitas perempuan yang diinginkan pihak laki-laki, perilaku kesehariannya dan pergaulannya dengan tetangga sekitar rumahnya, kecantikan paras wajahnya dan tentunya status perempuan tersebut sudah dalam pinangan orang lain atau tidak.

Setelah mendapatkan informasi mengenai hal-hal tersebut, kemudian Tatuha Kampung melakukan perhitungan tingkat kecocokan antara laki-laki dan perempuan yang diinginkannya, dengan cara menulis nama dari laki-laki dan perempuan dalam bentuk huruf Arab, kemudian menjumlahkan titik yang terdapat pada huruf Arab tersebut. Dari hasil penjumlahan itulah Tatuha Kampung mengambil kesimpulan mengenai tingkat kecocokan antara laki-laki dan perempuan tersebut.

Jadi, pada intinya prosesi ini adalah penentuan laki-laki dan perempuan tersebut dapat melangsungkan peminangan atau tidak. Sebab pada prosesi inilah Tatuha Kampung mengambil kesimpulan bahwa antara laki-laki tersebut dapat berjodoh dengan perempuan incaranya atau tidak, yang didasari pada hasil perhitungan Tatuha Kampung terhadap jumlah titik yang terdapat pada nama kedua belah pihak dalam bentuk huruf Arab, meskipun hasil pertanyaan mengenai kriteria perempuan yang diinginkan oleh pihak laki-laki menyatakan sesuai dengan keinginan dari pihak laki-laki.

Adapun konsepsi Khitbah yang termaktub dalam kitab Fiqih Sunnah karangan Sayyid Sabiq menyatakan bahwa :

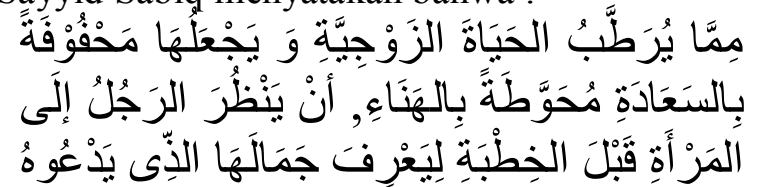

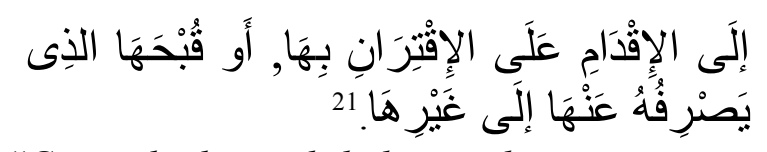

"Guna baiknya kehidupan bersuami istri, kesejahteraan dan ketenteramannya, seyogyanyalah laki-laki lebih dahulu melihat perempuan yang akan dipinangnya, sehingga dapat diketahui kecantikannya yang bisa menjadi salah satu faktor menggalakkan dia untuk mempersuntingnya, atau untuk mengetahui cacat-celanya yang bisa menjadi penyebab kegagalannya sehingga berganti mengambil orang lain, 22

Apabila ditinjau dari konsepsi Khitbah yang termaktub dalam kitab Fiqih Sunnah antara prosesi ini dengan konsep Khitbah tersebut, penulis tidak mendapati kesesuaiannya mengenai perhitungan jumlah titik pada nama kedua belah pihak yang berbentuk huruf Arab, yang menjadi patokan Tatuha Kampung dalam menentukan tingkat kecocokan dan keberjodohan antara laki-laki dan perempuan tersebut dengan ketentuan melihat pinangan yang termaktub dalam kitab Fiqih Sunnah karangan Sayyid Sabiq. Sebab ketentuan melihat pinangan yang termaktub dalam kitab Fiqih Sunnah mengindikasikan hanya dengan cara melihat dan mengetahui segala macam kondisi yang berkaitan dengan perempuan tersebutlah, pihak laki-laki dapat menentukan kecocokannya dengan perempuan yang diinginkannya, tidak dari hasil penjumlahan titik yang terdapat pada nama kedua belah pihak dalam bentuk huruf Arab. Sedangkan perhitungan jumlah titik pada nama kedua belah pihak dalam bentuk huruf Arab yang menjadi patokan kecocokan kedua belah pihak hanyalah ilmu perhitungan yang diwariskan secara turun temurun dari nenek moyang Tatuha Kampung yang digunakan untuk menghitung kecocokan antara laki-laki dan perempuan yang ingin menikah, dan dalam Agama Islam tidak diajarkan mengenai perhitungan tersebut digunakan dalam mengitung tingkat kecocokan antara kedua belah pihak, serta tidak terdapat pula dalam undang-undang yang berlaku di Indonesia. Maka dari itu antara prosesi perhitungan yang digunakan Tatuha Kampung dalam

\footnotetext{
${ }^{21}$ Sabiq, Fikih Sunnah, Juz II, h. 18.

${ }^{22}$ Sabiq, Fikih Sunnah 6, terj. Drs. Moh Thalib, h. 35.
} 
menentukan kecocokan kedua belah pihak tidak sesuai dengan konsepsi Khitbah dalam kitab Fiqih Sunnah karangan Sayyid Sabiq, ajaran Agama Islam dan perundang-undangan yang berlaku di Indonesia.

dalam $\begin{array}{ccc}\text { Sedangkan upaya Tatuha Kampung } \\ \text { mencari informasi }\end{array}$ perekonomian keluarga tersebut, tingkat religiusitas perempuan yang diinginkan pihak lakilaki, perilaku kesehariannya dan pergaulannya dengan tetangga sekitar rumahnya, kecantikan paras wajahnya dan tentunya status perempuan tersebut sudah dalam pinangan orang lain atau tidak, adalah sesuai dengan ketentuan dalam kitab Fiqih Sunnah karangan Sayyid Sabiq.

Sebab upaya yang dilakukan oleh Tatuha Kampung dalam mencari informasi tersebut tercantum dalam kitab Fiqih Sunnah karangan Sayyid Sabiq, yaitu:

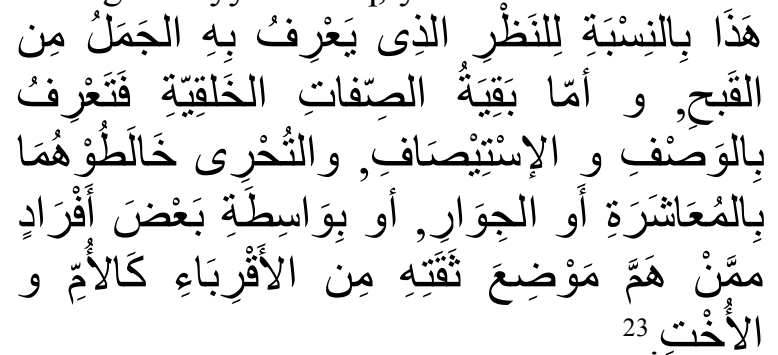

"dengan melihat, dapat diketahui cantik atau jeleknya seseorang perempuan. Adapun sifatsifat yang bertalian dengan akhlak, dapatlah diketahui dari sifat lahirnya atau ditanyai atau bertanya kepada mereka-mereka yang dekat dengannya, atau mellalui tetangganya, atau dengan perantara menanyai kalangan keluarganya yang sangat dipercayainya seperti ibu dan saudara-saudara perempuannya",24

Selain itu hal-hal yang menjadi pertanyaan Tatuha Kampung terhadap pihak perempuan tersebut sesuai dengan salah satu Hadits yang berbunyi :

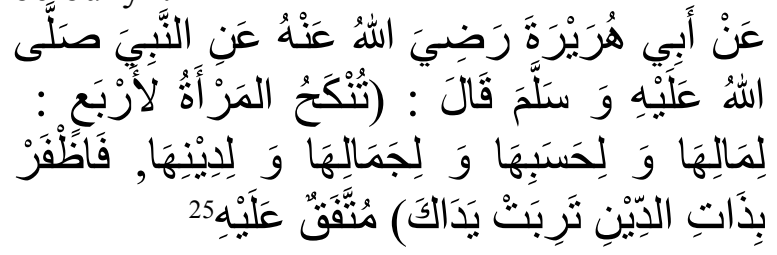

\footnotetext{
${ }^{23}$ Sabiq, Fikih Sunnah, Juz II, h. 19.

${ }^{24}$ Sabiq, Fikih Sunnah 6, terj. Drs. Moh Thalib, h. 37.

${ }^{25}$ Suwandi dan Ahmad Izzuddin (eds), Pedoman Qira'ah Al-Kutub, Tahfidz, dan Reading Texts, (Malang: Laboratorium Turats Universitas Islam Negeri Maulana Malik Ibrahim Malang Fakultas Syari’ah, 2009). h. 27.
}

Artinya :"Dari Abu Hurairah R.A, dari Nabi Shallallahu 'Alaihi wa Sallama beliau bersabda: (wanita dinikahi karena empat hal : karena Hartanya dan karena keturunannya dan karena kecantikannya dan karena agamanya, dapatkanlah wanita yang taat beragama, engkau akan berbahagia)" Muttafaq 'Alaih.

Pemahaman dari penulis mengenai prosesi Tuntung Pandang yang dilakukan oleh Tatuha Kampung pada masyarakat Suku Banjar yang berdomisili di Desa Awang Bangkal Barat adalah pada satu sisi ada yang sesuai dan pada sisi lain tidak ada kesesuaian dengan konsepsi Khitbah dalam kitab Fiqih Sunnah karangan Sayyid Sabiq. Satu sisi yang terdapat kesesuaiannya adalah antara konsep Khitbah Sayyid Sabiq yang termaktub dalam kitab Fiqih Sunnah dengan upaya pencarian informasi mengenai kondisi dan status perempuan incaran pihak laki-laki yang dilakukan oleh Tatuha Kampung terhadap pe-rempuan tersebut. Sedangkan satu sisi yang tidak terdapat kesesuaiannya adalah antara konsepsi Khitbah Sayyid Sabiq yang termaktub dalam kitab Fiqih Sunnah dengan upaya Tatuha Kampung dalam perhitungan tingkat kecocokan melalui nama kedua belah pihak yang menjadi kesimpulan terhadap laki-laki dan perempuan tersebut dapat berjodoh atau tidak.

\section{Kesimpulan.}

Dari paparan data dan hasil penelitian yang telah penulis lakukan, maka selanjutnya penulis akan mengambil kesimpulan terhadap penelitian kali ini, yaitu:

Tinjauan konsepsi Khitbah Sayyid Sabiq terhadap pelaksanaan Tradisi Basasuluh Suku Banjar adalah :

Pada tahapan pertama yaitu prosesi Bacarian Tatuha Kampung tidak ada kesesuaian antara prosesi ini dengan konsepsi Khitbah yang termaktub dalam Kitab Fiqih Sunnah karangan Sayyid Sabiq. Sebab maksud dan tujuan dari prosesi Bacarian Tatuha Kampung berbeda dengan maksud dan tujuan dari persyaratan yang harus dipenuhi oleh perempuan yang akan dipinang, sebagaimana termaktub dalam kitab Fiqih Sunnah karangan Sayyid Sabiq.

Kemudian pada tahapan kedua yaitu prosesi Bapara, terdapat kesesuaian antara prosesi ini 
dengan konsepsi Khitbah yang termaktub dalam kitab Fiqih Sunnah karangan Sayyid Sabiq. Kesesuaian tersebut terletak pada pelimpahan kuasa kepada Tatuha Kampung untuk mencarikan informasi mengenai perempuan yang diinginkan oleh pihak laki-laki.. Pada tahapan yang ketiga ini yaitu prosesi Tuntung Pandang, terdapat dua hal yang terjadi dalam prosesi ini, yaitu :

Hal yang pertama adalah Tatuha Kampung mencari informasi mengenai kondisi dan status perempuan yang diinginkan pihak laki-laki. Dalam hal ini memiliki kesesuaian terhadap konsepsi Khitbah yang termaktub dalam kitab Fiqih Sunnah karangan Syyid Sabiq.

Adapun hal yang kedua adalah setelah Tatuha Kampung mendapatkan infor-masi tersebut, beliau melakukan per-hitungan jumlah titik pada nama kedua belah pihak yang berbentuk huruf Arab, yang menjadi patokan Tatuha Kampung dalam menentukan tingkat kecocokan dan keberjodohan antara laki-laki dan perempuan tersebut serta dapat berimplikasi pada keberlanjutan ke-inginan pihak laki-laki yang ingin meminang perempuan idamannya. Dalam hal ini tidak terdapat kesesuaiani dengan ke-tentuan konsepsi Khitbah dalam kitab Fiqih Sunnah karangan Sayyid Sabiq.

\section{A. Kitab}

\section{DAFTAR PUSTAKA}

Al-Qur'an Al-Karim

Sabiq. Sayyid, 2009. Fikih Sunnah, Juz II

Cet. XXI; Dâr al-Hadîts al-Qâhirah

\section{B. Buku}

Amiruddin, dan Zainal Asikin. 2004. Pengantar Metode Penelitian Hukum. Jakarta: PT Raja Grafindo Persada.

Ideham, Suriansyah dan Sjarifuddin. 2007. Urang Banjar dan Kebudayaannya. Banjarmasin: Pemerintah Propinsi Kalimantan Selatan.

Seman. Syamsiar. 2011. Perkaawinan Adat Banjar Kalimantan Selatan. Cet. 6. Banjarmasin: Lembaga Pengkajian \& Pelestarian Budaya Banjar.
Fakultas Syari'ah. 2012. Pedoman Penelitian Karya Ilmiah. Malang: Fakultas Syariah.

Sugiyono, Prof. Dr. 2008. Metode Penelitian Kuantitatif, Kualitatif dan $R \& D$. Bandung: Alfabeta.

Suwandi dan Ahmad Izzuddin, 2009. Pedoman Qira'ah Al-Kutub, Tahfidz, dan Reading Texts, Malang: Laboratorium Turats Universitas Islam Negeri Maulana Malik Ibrahim Malang Fakultas Syari'ah,

\section{Buku Terjemahan}

Sabiq, Sayyid. Fiqih Sunnah 6. Terjemahan. Drs. Moh. Thalib. Cet. 1. Bandung: PT. Alma'arif, 1980.

\section{Dokumen Resmi}

Kompilasi Hukum Islam

E. Tulisan Internet

anastasyaitsreal.blogspot.com/2012/11/perkawi nan-adat-banjar-kecamatan-nagara/, (diakses pada tanggal 9 Mei 2013) 